Jarostaw Michalski*

Toruń

\title{
Konstruowanie tożsamości podmiotowej w kontekście kategorii sensu w pedagogice
}

Poszukiwania sensu życia towarzyszą człowiekowi od początku jego istnienia. Pytania o sens własnej egzystencji, celowość istnienia świata, $\mathrm{z}$ różną intensywnością pojawiają się w świadomości człowieka. Każdy stawia sobie pytania: Kim jestem? Po co żyję? Jaki jest sens życia? Pytania te nasuwają się szczególnie wtedy, gdy ludzką egzystencję dotyka jakieś wydarzenie, nieszczęście bądź cierpienie, kiedy człowiek znajdzie się w trudnej, nieokreślonej dla siebie sytuacji. Zagadnienie sensu życia interesowało nie tylko tak zwanych zwykłych ludzi, lecz także badaczy filozofii, socjologii czy przedstawicieli innych dyscyplin naukowych, w tym psychologii oraz pedagogiki. Jednak z praktycznego punktu widzenia pozostaje ważny problem, jak zagadnienie sensu życia ożywić w wychowaniu, w działalności edukacyjnej i w myśleniu pedagogicznym, jak - w ten sposób - pomóc ludziom wchodzić na drogę pełni bytu i życia, drogę zorientowaną na cele.

Zdaniem V. E. Frankla, sens życia to umiejętność odnalezienia i wykonywania szczególnych zadań, które w przypadku każdej jednostki są indywidualne. Owe zadania nie są przypadkowe, a zaangażowanie w ich realizacje wynika z powołania oraz z poczucia odpowiedzialności. Często i chętnie cytował on F. W. Nietzschego: „Ten, kto ma po co żyć, potrafi znieść niemal każde jak"'.

Pytanie o sens posiada duże znaczenie dla pedagogiki. Przy próbie silniejszego podkreślenia tej tezy na drodze przedstawienia odpowiednich

* Ks. prof. dr hab. Jarosław Michalski jest kierownikiem Katedry Filozofii Wychowania w Wydziale Nauk Pedagogicznych Uniwersytetu Mikołaja Kopernika w Toruniu.

1 V. E. Frank1, Das Leiden am sinnlosen Leben, „Universitas” 2 (1987), s. 155. 
argumentów, szczególnego znaczenia nabiera między innymi myśl i dzieło V. E. Frankla. Oczywiście związki te są istotne i możliwe przy założeniu, iż rozpatrujemy je w perspektywie pedagogiki filozoficzno-transcendentalnej. Zwrócenie uwagi na ten punkt wyjścia posiada znaczenie o tyle, że każdy typ zorientowania pedagogicznego zawiera, tak czy inaczej, swe przedzałożenia filozoficzne co do natury człowieka, jego znaczenia i miejsca w świecie. Wynika stąd swoisty rodzaj wyjaśniania $\mathrm{i}$ argumentowania zawartego $\mathrm{w}$ pracy kluczowego problemu pytania o sens oraz jego związki z teorią i praktyką pedagogiczną. Jeśli na przykład pytanie o sens miałoby być badane i analizowane w relacji do kształcenia lub też „sens” jako powinność miałby uzyskać rangę przedmiotu badania, to wówczas przyjęta perspektywa metodologiczna pedagogiki filozoficzno-transcendentalnej wyznaczać będzie sposób i przebieg zastosowanych badań.

Filozoficzno-pedagogiczna kategoria sensu jako specyficzny horyzont egzystencji ludzkiej potraktowana może być jako wyzwanie, sposób myślenia i jako realna rzeczywistość. Wyzwanie, ponieważ, by w sposób autentyczny doświadczyć relacji z drugim człowiekiem, trzeba zrobić krok w jego stronę, wyjść mu naprzeciw. Należy opuścić swoje monologiczne ufortyfikowanie i doświadczyć dialogiczności z drugim jako osobą. Sposób myślenia, ponieważ z niego wyłania się działanie człowieka odzwierciedlające stosunek do rzeczywistości. Nie można bowiem realizować celów, ideałów wypełniać sensem życia bez przełamywania schematów i bez zmiany swojego, często instrumentalnego traktowania drugiego człowieka. Rzeczywistość, ponieważ fenomen sensu jest czymś realnie powiązanym $\mathrm{z}$ rdzeniem człowieka, z rdzeniem jego ludzkich spraw, czymś najbardziej pierwotnym i niedającym się zastapić niczym innym. Tak pojmowana kategoria sensu jest czymś, czego obecność lub brak, autentyczność bądź mistyfikacja, afirmacja lub deprecjacja wywiera realny i wymierny wpływ na jakość życia każdego człowieka. Osobowy wymiar sensu kształtuje typy odniesień i powiązań, relacje i motywacje, konstytuując tym samym określoną postać interakcji międzyludzkich.

Człowiek jako podmiot pedagogiki z uwagi na swą podatność na kształcenie $\mathrm{w}$ procesie swojego stawania się $\mathrm{w}$ pełni osobą powinien kierować się zasadą wolności, postrzegać własne samostanowienie i autonomię, dojrzałość i zdolność do wydawania sądów, jeśli nie chce zostać sprowadzony do przedmiotu lub narzędzia w rękach drugiego człowieka. Wspólną płaszczyzną analizy egzystencjalnej, zaproponowanej przez Franka, jak i pedagogiki filozoficzno-transcendentalnej, jest bowiem traktowanie człowieka w jego pełnym osobowym i integralnym wymiarze ${ }^{2}$.

2 J. Michalski, Sens życia a pedagogika. Impulsy myśli Viktora E. Frankla, Toruń 2011, s. 11 . 
Poczucie sensu życia wiąże się u wielu osób z bezpośrednimi celami, będącymi w „zasięgu ręki”. Będą to między innymi bliskie i serdeczne kontakty $\mathrm{z}$ innymi (przede wszystkim w rodzinie), świadomość bycia potrzebnym dla innych, aktywność zewnętrzna prowadząca do osiagnięcia zamierzonych efektów, poszukiwanie i odkrywanie prawdy, działalność w sferze politycznej, praca zawodowa, działalność twórcza. Niekiedy samo poszukiwanie sensu, nawet bez jego znalezienia, nadaje życiu ludzkiemu celowość i jakąś kierunkowość. W krańcowych przypadkach, co brzmi paradoksalnie, próba wykreślenia sensu z życia nadaje mu jakiś sens (tzw. pozytywny nihilizm)³.

„Poszukiwanie prawdy to odwieczne i powszechne dążenie istot ludzkich. Obecnie jednak wielu spośród nas wydaje się z niego w pełni świadomie rezygnować" ${ }^{4}$ - czytamy w pracy Felipe Fernándeza-Armesto Historia prawdy. Lecz czy możemy, czy mamy prawo, „odwracać się” od prawdy i czym właściwie jest ta, o którą zapytujemy? Prawda, jakkolwiek ujmowana, jest nierozłączną życiu człowieka. Zapytywanie o to, czym jest, dążenie ku niej, to zarazem odkrywanie istoty życia, jego sensu. Rzec można, że poszukiwanie prawdy przynależne jest naturze ludzkiej. To, kim jest człowiek, zależy od tego, jak ustosunkowuje się on do podstawowego wyznacznika własnej egzystencji - do jej sensu. Świadomość celowości bycia oraz możliwość aktywnego uczestniczenia w konstytucji telos jawią się w tym miejscu jako prawda egzystencji, czy inaczej, prawdą egzystencji jest pytanie o sens jej bycia. Egzystencja jako taka jest właściwym człowiekowi sposobem istnienia, który zawiera się w ciągłym zapytywaniu o cel bycia i nieustannym projektowaniu siebie samego $\mathrm{w}$ odniesieniu do tego kluczowego pytania właśnie. Tylko w tej perspektywie możliwy jest właściwy wzrost i rozwój istoty ludzkiej w jej pełnym wymiarze. Stąd pedagogika, jako zatroskana o los człowieka, jego wychowanie i edukację, kwestii prawdy i sensu nie może pomijać, a mieć szczególnie na względzie w swej teorii i praktyce badawczej. Tak tylko zapewnić można jednostce optymalne kształtowanie jej osobowości - poprzez zdobywanie wiedzy o sobie i otaczającej rzeczywistości - by mogła w pełni czerpać $\mathrm{z}$ właściwego sobie potencjału. Podkreślmy zatem, że sens życia i zapytywanie o sens jest właściwością egzystencji, czyli jej prawda, dlatego koniecznym jest, by owo kluczowe dla człowieka pytanie było obecne w dyskursie pedagogicznym.

Człowiek jest, jak to zaznaczono wyżej, nie inaczej, jak tylko poprzez swą egzystencję, to ona stanowi ramy bycia istotą ludzką, lecz także stwarza możliwości przekraczania właściwej człowiekowi immanencji, ku temu, co poza, ponad horyzontem anthropos. Płaszczyzna egzystencjalna jest zatem

3 V. E. Frank1, Die Psychotherapie in der Praxis, Wien 1982, s. 78.

${ }^{4}$ F. Fernández-Armesto, Historia prawdy, Poznań 1999, s. 10. 
podstawą konstytuowania człowieka jako człowieka, w stronę jego „górnych możliwości”, w stronę pełni. Jest także punktem wyjścia ku rzeczywistości transcendentnej, ku sacrum. Jest, mówiąc jeszcze inaczej, miejscem kreacji czy też nadawania sensu ludzkiemu życiu. Lecz czym właściwie jest egzystencja i jak ją rozumieć? Sięgając etymologii, termin ten wywodzi się z łacińskiego existentia, czyli istnienie. Stąd pierwotnie pojęcie egzystencji thumaczone jest jako: byt, istnienie, bytowanie, warunki życias. Współcześnie, za sprawą egzystencjalizmu ${ }^{6}$ znaczenie terminu uległo zawężeniu i gdy traktujemy o egzystencji, rozumiemy ją jako „swoisty sposób istnienia właściwy jedynie człowiekowi, czyli istnienie łączy się z projektowaniem własnego bytu, z wolnością wyboru, świadomością narodzin i śmierci" z nadawaniem celu i sensu własnemu życiu. Rzec można: jeśli traktujemy o egzystencji jako byciu, traktujemy zarazem o sensie tego bycia.

I tak, z jednej strony egzystencja otwiera pole możliwości usensawniania życia, z drugiej zaś, gdy zanegujemy wszelkie odniesienie do sensu tego życia, zniesiemy także i samą egzystencję. Przyjmując zatem pierwotną i podstawową ważność egzystencji ludzkiej, nie można jej pominąć w nauce, tyczącej bezpośrednio człowieka, jaką jest pedagogika. To nauki pedagogiczne roszczą sobie prawo mówienia o człowieku, jego wzroście i rozwoju, o procesach kształtowania osoby, jaką jest, a raczej nieustannie się staje. Jeśli owo stawanie się człowiekiem warunkowane jest przez jego własną egzystencję, to i pedagogika jako nauka powinna w sposób szczególny być zatroskaną o tę płaszczyznę ludzkiego bycia. W. Pasterniak pisze:

Rozjaśnieniu ludzkiej egzystencji służy kultura, religia, ale przede wszystkim edukacja. To ona bowiem w mniejszym lub większym stopniu pozwala przyswajać i tworzyć dzieła kultury i nauki, zrozumieć religię i uczestniczyć w niej świadomie. To ona kreuje człowieka i jego człowieczeństwo, uwrażliwia na Dobro, Prawdę i Piękno, pozwala na uniezależnienie się od wszelkiego zła. Edukacja otwiera bramy wolności, a zamyka drogę do samowoli ${ }^{8}$.

Czy też w innym miejscu tego samego dzieła: „Semantyka pytania: kim ma (powinien) być człowiek wyznacza sens ludzkiej egzystencji. Pytanie to stawia pedagogika od zarania swego istnienia, wcześniej postawiła je filozofia,

${ }^{5}$ W. Kopaliński, Stownik wyrazów obcych i zwrotów obcojęzycznych, Warszawa 1990, s. 139.

${ }^{6}$ Egzystencjalizm - kierunek filozoficzny zapoczątkowany przez S. Kierkegaarda, który przedmiotem swych badań czyni egzystencję człowieka.

${ }^{7}$ Filozofia. Leksykon PWN, Warszawa 2000, s. 110.

${ }^{8}$ W. Pasterniak, Rozjaśnić egzystencję. O dylematach i rozdrożach edukacji, Poznań 2001, s. 5. 
z której pedagogika wyrosła i na fundamencie której się wspiera, a najwcześniej sformułowały je religie. W pierwotnym zatem ujęciu pytanie to jest pytaniem religijnym".

Religia jest bowiem na przykład dla V. Frankla wartością autonomiczną, ale spełnia także wiele innych, istotnych funkcji w życiu osobowym człowieka, jak również wywiera wpływ na życie społeczne. Może ona w znacznym stopniu pomagać człowiekowi w jego lepszym funkcjonowaniu wewnętrznym, jak i w podejmowaniu zewnętrznej aktywności. Istotne wydaje się podkreślenie, że religijność, czyli subiektywny stosunek do religii, jako zbioru pewnych prawd, dogmatów, systemu norm postępowania, obrzędów, które regulują stosunek do Boga, może odgrywać ważną rolę w kształtowaniu osobowości człowieka oraz jego postawy życiowej. Wartości religijne stanowią ważny punkt odniesienia i drogowskaz w rozwoju osobowości. Mogą przyczyniać się w różnym stopniu, w zależności od miejsca, jakie zajmują w strukturze osobowości, do jej rozwoju. Dzięki nim człowiek może zaspakajać swoje potrzeby i odnaleźć odpowiedź na podstawowe pytania dotyczące istnienia człowieka i świata. Na nich, podobnie jak na potrzebach, może być budowany sens życia człowieka ${ }^{10}$.

Problematyka sensu życia jest niezwykle ważna w perspektywie egzystencjalnej. Jest to zagadnienie, które warto podejmować, zwłaszcza w czasach obecnego kryzysu moralnego, który często prowadzi do zagubienia sensu życia. W szybko zmieniającym się świecie poszerzają się kręgi osób poddających się uczuciom bezsensu życia, wzrasta ilość tak zwanych egzystencjalnych frustracji. Kryzys sensu życia i odczuwanie bezsensu rodzą się we współczesnych warunkach na skutek różnorodnych rozczarowań, ale także przede wszystkim na skutek negatywnych przemian w sferze wartości i norm.

Zakwestionowanie wartości i kryzys tożsamości, przez który przechodzi dzisiaj znaczna część ludzi, zwłaszcza młodych, zobowiązuje do przezwyciężania go oraz podjęcia na nowo wysiłków na polu badań i dociekań naukowych. Kryzys globalny, który dotknął ekonomię, politykę, kulturę, moralność, religijność, w końcu samego człowieka, domaga się szczególnej integracji, współpracy, poczucia odpowiedzialności i twórczego dialogu w zakresie budowania nowego ładu i nowego porządku normatywnego, zwłaszcza zaś instytucji odpowiedzialnych za wychowanie młodego pokolenia.

$\mathrm{Z}$ praktycznego punktu widzenia powstaje zatem ważny problem, jak zagadnienie sensu życia ożywić w wychowaniu, w edukacji, nie tylko reli-

9 Tamże, s. 30.

10 J. Michalski, Godność człowieka wartościq ontyczno-wychowawcza, ,Studia Warmińskie" 51 (2006), s. 48. 
gijnej, ale szerszym myśleniu pedagogicznym, jak pomóc ludziom w odnajdywaniu pełni bytu i życia. Warto zatem, a nawet wydaje się to konieczne, zainteresowanie problematyką sensu życia podtrzymywać, zarówno w rozważaniach teoretycznych, jak i działaniach praktycznych.

To, jaki ma być człowiek, antycypacja siebie pożądanego, idealnego leży u podłoża nieustannego ruchu, ciagłego stwarzania własnego Ja - ku Ja lepszemu, doskonalszemu. Człowieczeństwo wiąże się z duchową sferą bytu człowieka. Według V. Frankla człowiek jest właściwie i przede wszystkim „istotą duchową". Duchowy wymiar życia nie podlega uprzedmiotowieniu i obiektywizacji i do niego bezpośrednio odnosi się egzystencja. „Egzystencja nigdy nie jawi się przed mymi oczami jako przedmiot, raczej stoi ona zawsze za moim myśleniem, za mną jako podmiot. I tak w ostateczności egzystencja to misterium" ". By mówić adekwatnie o egzystencji, V. E. Frankl odwołuje się do analizy egzystencjalnej, która w jego ujęciu nie stanowi analizy samej egzystencji, a jest raczej zwróceniem się w jej stronę, co ma uświadamiać możliwości realizacji wartości i sensu życia. „Analiza egzystencjalna jest analizą sensowności. Przedmiotem analizy egzystencjalnej jest właśnie sensowność istnienia. Przy tym dla niej nie podlega dyskusji jedno, a mianowicie, że człowiek jest zorientowany na sens. Analiza egzystencjalna widzi życie ludzkie jako przepojone dążeniem do sensu"'2, czy też ,analiza egzystencjalna w centrum swego pola widzenia stawia orientowanie się człowieka na sens i dążenie $k u$ wartościom"'13. Nie można także zapomnieć, twierdzi autor Homo patiens, że analiza odwołuje się do godności człowieka rozumianej jako wartość sama w sobie, a także do odpowiedzialności za swój własny los, za realizację wartości i odkrywanie, czy też kreowanie sensu własnego życia. V. E. Frankl wprowadza także rozróżnienie na „życie faktyczne”, którym jest „byt ludzki dany”, oraz „życie fakultatywne”, jako „byt ludzki zadany”. „Człowiek, bowiem nigdy nie jest człowiekiem, ale dopiero się nim staje, człowiek nie jest tym, który mógłby o sobie powiedzieć: Jestem, który jestem - natomiast może on o sobie powiedzieć tylko: Jestem, który będę"14, czy też jak mówi przywołany przez austriackiego psychiatrę Jaspers: „byt ludzki [...] nigdy nie jest, lecz raczej każdorazowo rozstrzyga, czym jest"15. Dążenie w kierunku od bytu faktycznego do fakultatywnego, czyli inaczej rzecz ujmując, dążenie od tego, kim jestem do tego, kim mogę i mam być, to dążenie do istoty bycia, do jego esencji.

\footnotetext{
11 V. E. Frankl, Homo patiens, Warszawa 1998, s. 20.

12 Tamże, s. 43.

13 Tamże, s. 27.

14 Tamże, s. 68.

15 Tamże, s. 75.
} 
Ważnym podkreślenia jest także to, iż człowieka nie można i nie należy ujmować inaczej jak całość, gdyż tak tylko (w całościowym ujęciu) możemy w ogóle mówić o człowieku. Istota owej całości, istota człowieczeństwa to nieustanne, niekończące się otwieranie się na możliwości bycia za każdym razem jednej i niepowtarzalnej osoby. Możliwości w ich całokształcie „to spełnianie sensu i urzeczywistnianie wartości" ${ }^{16}$. Człowiek rozumiany jako otwarcie jest projekcją siebie samego w czas, jest wykraczaniem ku własnym, sobie tylko właściwym możliwościom. Możliwości są miejscem spełniania tego, na co w otwarciu i poprzez otwarcie nakierowuja, czy inaczej, ku czemu wychodza. Ku zaistnieniu rzeczywistemu tego, co dopiero wyrasta z możliwości. Realizację potencjału tkwiącego w możliwości możemy nazwać spełnianiem. Spełnienie natomiast doświadczane w partycypacji siebie w spełnianiu jest wkraczaniem w płaszczyznę prawdy i sensu. Sens, jaki zostaje nam w ludzkiej egzystencji otwarty, jawi się jako konieczna podstawa człowieczeństwa, którą zarazem to człowieczeństwo warunkuje. Człowiek rozumiany jako permanentne stawanie się, daje rację bytu swemu jestestwu, jeśli wspiera egzystencję na podstawie-sensie, czyli prawdzie o sobie samym. Z niej dopiero wypływa możliwość ruchu, możliwość wykraczania poza własne ,ja”, możliwość spełniania siebie.

Samo pojęcie człowieczeństwa, które zostało tu przywołane, odkrywa, na co wskazuje W. Stróżewski, na integralność nauk, jakimi są filozofia, czyli obszar namysłu nad człowiekiem, oraz pedagogika postrzegająca jednostkę ludzką jako tworzywo wychowawcze. „Człowieczeństwo, to po łacinie $h u$ manitas. W jej idei znajdują szczególne miejsce spotkania filozofia i paideia; pierwsza by ją odsłaniać, druga - by pomagać wedle niej właściwie kształtować człowieka" ${ }^{17}$. Tak zatem filozofia z jednej strony wprowadza w obszar namysłu nad człowiekiem, nad jego egzystencją i prawdą tej egzystencji, $\mathrm{z}$ drugiej natomiast pedagogika, czerpiąc $\mathrm{z}$ owego namysłu nadbudowuje nad nim obszar związany z problematyką kształtowania i wychowywania osoby ludzkiej. W ten sposób egzystencja zostaje bezpośrednio odniesiona do procesów i zadań edukacyjnych. Teresa Borowska rozwija powyższą myśl pisząc: „Egzystencja jako zadanie edukacyjne ma charakter podmiotowy, charakteryzuje się zdolnością do przekraczania uwarunkowań, autodystansowania się wobec zjawisk, problemów i odnoszenia się $k u$ komuś lub $k u$ czemuś"18.

Pomimo jednak tak dużej wagi egzystencjalnego wymiaru życia człowieka dla edukacji, trzeba podkreślić, iż istnieje właśnie w tej dziedzinie

16 Tamże, s. 18.

17 W. Stróżewski, W kręgu wartości, Kraków 1992, s. 37.

18 T. Borowska, Pedagogika ograniczeń ludzkiej egzystencji, Warszawa 1998, s. 10. 
luka pośród dyskursu pedagogicznego. W pracy Pedagogika ograniczeń ludzkiej egzystencji jej autorka stwierdza „problemy egzystencjalne zdają się wciąż lokować we współczesnej pedagogice w obszarze nieobecnych dyskursów" ${ }^{19}$. Brak ów jawi się jako istotny czy nawet podstawowy problem dotyczący teorii i praktyki wychowawczej. Istotą bowiem edukacji, jako nauki zajmującej się człowiekiem, jest dbałość o rozwój istoty ludzkiej w całej jej pełni, czyli dbałość o spełnianie człowieczeństwa, co nie może być możliwe bez odniesień do pytania o sens bycia człowiekiem i prawdę człowieczeństwa. Takie spojrzenie na osobę sięga korzeni powstania pedagogiki. Tak zatem u podstaw, u początków świadomego zaistnienia omawianej dziedziny wiedzy, leżą założenia filozoficzne, z których dopiero pedagogika się wyłania. Filozofia natomiast, która punktem wyjścia wszelkiego namysłu uczyniła zdziwienie światem, o świat ten nieustannie zapytywała. Przedmiotem pytań stał się też sam człowiek, będący częścią otaczającej rzeczywistości. Stąd kluczowe zagadnienia tyczą tutaj między innymi istoty bycia człowiekiem, celu jego zaistnienia na ziemi czy sensu życia. Filozofia zatroskana jest także o sferę moralną egzystencji, dywagując na temat dobra i zła, tego, „co słuszne” i „co niesłuszne”, czy tego, co czyni życie wartościowym, a co mu wartość odbiera.

Stąd i pedagogika, jako że z filozofii wyrosła, w pierwszym planie swych rozważań sytuowała pytanie o człowieka. I tak jak filozofia szuka odpowiedzi na pytanie, kim jest człowiek, tak pedagogika zapytuje o to, jaki ma i powinien on byćc ${ }^{20}$. Inaczej rzecz ujmując, filozofia to refleksja nad istotą humanitas. Pedagogika natomiast zajmuje się realizacją wymienionej idei, gdyż ,jej przedmiotem jest przecież żywy człowiek, a celem tworzenie czy kształtowanie, jeśli nie wręcz przywoływanie do bytu jego człowieczeństwa" ${ }^{21}$. Pisze W. Stróżewski także, iż przejście od filozofii do paidei to przejście do działań mających na celu właściwe wychowanie człowiekaa ${ }^{22}$, czyli wychowanie kształtujące prawdziwe człowieczeństwo. To ostatnie, o czym już była mowa, jest idea, celem, ku któremu zmierza proces kształtowania człowieka, jest idealnym obrazem osoby ludzkiej, ideałem, który poprzez nieustanny dynamizm rozwoju zostaje urzeczywistniany. By jednak móc rozpocząc realizację wyznaczonego celu, czyli niełatwą „wędrówkę" od ,ja" rzeczywistego w stronę ,ja” idealnego, trzeba wcześniej postawić pytanie o sens owej przemiany. Jeśli zdefiniujemy życie człowieka jako nieustanną przemianę i rozwój, wówczas pytanie o sens owej dynamiki będzie

\footnotetext{
19 Tamże, s. 9.

${ }^{20}$ W. Stróżewki, dz. cyt., s. 37.

21 Tamże, s. 41.

22 Tamże, s. 39.
} 
również pytaniem o sens samego życia. Wróciliśmy więc do tego, co dla nas istotne, do pytania o sens życia. Pedagogia, chcąc wypełniać wyznaczone sobie zadania, nie może pomijać tego zasadniczego pytania. Celem edukacji jest dbałość o wzrost człowieka ku pełni jego możliwości, oraz takie kształtowanie i wychowywanie osoby ludzkiej, aby ideał człowieczeństwa mogła i umiała wcielać w życie. By to było możliwe, raz jeszcze powtórzmy, działalność edukacyjną wesprzeć należy na podstawie odniesień do sensu i zapytywania o ów sens.

Oczywiście, z praktycznego punktu widzenia pozostaje ważny problem, jak zagadnienie kształtowania sensu życia ożywić w życiu społecznym, w wychowaniu, w edukacji, w edukacji religijnej i w myśleniu pedagogicznym, jak pomóc ludziom wchodzić na drogę, która nie prowadzi do nicości, lecz ku pełni bytu i życia. Odpowiedzią na te wątpliwości może być pedagogiczne odczytanie propozycji V. E. Frankla i jego logoteorii. Taki cel przyświecał powstaniu niniejszej publikacji. W zamierzeniu autora nie miała ona jednak wyczerpywać problemu związków pedagogiki z teorią V. E. Frankla w perspektywie pytania o sens. Miała być natomiast przyczynkiem do dalszych pogłębionych analiz, które w konsekwencji doprowadzić moga do potraktowania problemu „sensu” i „sensu życia” jako istotnego przedmiotu rozstrzygnięć teoretyczno-pedagogicznych oraz do uznania ,pytania o sens" jako jednego z kluczowych obszarów praktyki oddziaływań wychowawczych.

„Pedagogiczność” teorii Frankla polega, jak zostało to wykazane, na istotnym podobieństwie $\mathrm{w}$ rozumieniu osoby, w którym podmiot definiowany jest jako cel sam w sobie i w tym aspekcie domagający się dla siebie poważania i godności. Podobnie jak nie da się skonstruować pedagogiki bez podmiotu, tak też bezpodstawne jest myślenie o sensie bez podmiotu, który do niego zdąża. Pedagogika i analiza egzystencjalna pozostają zdane na swój podmiot $-\mathrm{z}$ jednej strony na podstawie powiązanej z nim zdolności kształcenia, z drugiej - na podstawie przypisywanego mu wymiaru sensu - jego duchowości ${ }^{23}$.

Warunkiem wyjściowym i koniecznym zarówno logoterapii, jak i oddziaływań wychowawczych jest ich osobowy charakter. W obu obszarach zaistnienie takiej faktyczności nazywa się spotkaniem osób. Polega ono na dialogicznym, horyzontalnie i wertykalnie zorientowanym, w pełni satysfakcjonującym jednostkę sposobie bycia i spełniania siebie. Osiagalne jest to w sytuacji najgłębszych osobowych doświadczeń: w przyjaźni, w miłości, w religijnym doznaniu, w doświadczeniu egzystencjalnym itp. Jest to więc doznanie całościowe ludzi, które opisać można w języku egzystencjalno-

${ }^{23}$ J. Michalski, Sens, s. 159. 
-fenomenologicznym. Jako takie nie jest dostępne podejściu empirycznemu, które z natury swej musi „redukować” wielowymiarowo warunkowaną złożoność ludzkich doznań do zachowań bardziej prostych ${ }^{24}$.

Analiza egzystencjalna oraz logoteoria, podobnie jak pedagogika, wychodzą z koncepcji człowieka, które jego założenia biologiczno-mechanistyczne zdecydowanie pozostawiają w polu negacji. Dlatego modne dziś, a często przejęte $\mathrm{z}$ innych dyscyplin naukowych, takie terminy, jak: sygnał, bodziec, reakcja, informacja, interakcja, komunikacja, relacja itp., bez ich szczegółowego dookreślenia, zdają się gubić osobowy charakter bycia i doznań ludzi. Ujmują one raczej instrumentalną, czynnościową, zjawiskową stronę faktu ludzkiej egzystencji.

Należy zauważyć, że w spotkaniu musi zaistnieć na przykład relacja, komunikacja. Natomiast w zaistniałej relacji czy komunikacji niekoniecznie musi być obecne spotkanie. Rozumienie terminu „spotkanie” trzeba obwarować określonymi warunkami, aby można je było nazwać prawdziwie ludzkim. Jednym z tych warunków jest właśnie sens, który w dobie interakcji globalnej bywa często niedostrzegalny i pomijany. Spotkaniu wówczas zagraża wynaturzenie. Oznacza to, że mimo iż dochodzi do niego między ludźmi, może ono dokonywać się na poziomie subludzkim i mieć charakter czysto instrumentalny.

Buber i Ebner wskazują nie tylko na znaczenie spotkania, ale podkreślają również jego charakter dialogiczny. W tym miejscu warto jednak zwrócić uwagę, że z perspektywy logoteorii prawdziwy dialog nie może dojść do skutku tak długo, dopóki wymiar logosu nie zostanie przekroczony. Dialog bez logosu popada w monolog. Partnerzy dialogu nie są wówczas objęci intencjonalnym nastawieniem, ale tylko tym, aby samego siebie „wypowiedzieć". Transcendencja siebie oznacza tu, że być człowiekiem to być skierowanym ponad siebie samego, ku komuś lub czemuś, co nie jest mną samym, na coś lub ku komuś, na jakiś sens spełniany, albo osobę spotykaną w miłości. Intencjonalność aktów duchowych, podkreślanych w logoteorii, jest poznawczą stroną transcendowania siebie. Dialog, który ogranicza się do wypowiedzenia samego-siebie, odbiera ludzkiej egzystencji wyróżnienie transcendowania siebie. Prawdziwe spotkanie jest nie tylko zorientowane na logos, ale pomaga również człowiekowi w wyjściu ku logosowi, w przekraczaniu samego siebie ${ }^{25}$.

Dla pedagogiki wynikają stąd istotne konsekwencje. Otóż wszelka pedagogia bez logosu nie znajduje żadnych podstaw, ku którym moglibyśmy skierować naszą egzystencję. Ona zna tylko przyczyny, a te znajdują się nie

${ }^{24}$ Tamże, s. 161.

${ }^{25}$ V. E. Frank1, Der Wille zum Sinn, Wien 1972, s. 218-219. 
na zewnątrz w świecie, lecz w nas samych, w naszym własnym psychofizjologicznym wyposażeniu. Przyczyny nie są jednak tym samym co podstawy.

Frankl obrazuje, że jeśli ktoś kroi cebulę - płacze. Jego płacz ma przyczynę. Nie ma jednak żadnego powodu, żadnej podstawy do płaczu. W spotkaniu bowiem ,przekraczam samego siebie, jeśli ono jest prawdziwe i służy nie tylko do wypowiedzenia siebie. Przekraczam siebie, przekraczając logos. Pseudospotkanie bazuje nie na prawdziwym dialogu, lecz na dialogu bez logosu i dlatego służy tylko jako forum wyrażenia siebie"26.

Dominującymi cechami bytowania w autentycznym spotkaniu są: partnerstwo, uczestnictwo, pomocniczość, odpowiedzialność i wolnośćc ${ }^{27}$. Trzy pierwsze określenia odnoszą się przede wszystkim do społecznego wymiaru spotkania. Dwa ostatnie dotyczą tych wyróżnień, które przysługują człowiekowi jako osobie. Cechy te wynikają z analizy i rozumienia ontycznego statusu człowieka jako osoby - bliźniego. Spotkanie, realizowane w takiej atmosferze, ma szansę bycia twórczym, ale i właśnie wychowawczo-terapeutycznym.

Co zostało powiedziane do tej pory, ukazuje, iż pytanie o sens życia jest pytaniem wyróżniającym człowieka spośród innych stworzeń, jest podstawą konstytucji człowieczeństwa nadającą życiu ludzkiemu głębszy wymiar, wykraczającą poza sferę zwierzęca jego bytu. Pytanie o sens jest duchową potrzebą wpisaną $\mathrm{w}$ naturę homo sapiens. Potrzeby tej nie można zagłuszyć ani zniwelować, nie godząc przy tym w samego człowieka, w jego istotę. Relacja pomiędzy pytaniem o sens a odpowiedzią na nie rozgrywa się na dwu płaszczyznach: transcendencji i immanencji. Człowiek pyta o sens własnego życia, zwracając się ku sobie samemu, ku swojej istocie, ale także odnosząc się do tego, co poza tkanką jego indywidualnego bytu, ku temu, co transcendentne, co powiązane jest ze sferą sacrum. Na przecięciu obu osi dopiero możliwa staje się odpowiedź. Cóż jednak staje się z tak przedstawianą strukturą pytania o sens życia i strukturą samego sensu, gdy relacja pomiędzy transcendencją i immanencją zostaje zaburzona?

Właśnie z takim zaburzeniem relacji mamy do czynienia współcześnie. „Stabilny obraz” świata uległ bowiem załamaniu. Rzeczywistość porządkowana przez religię traciła stopniowo na znaczeniu. Oświecenie wraz ze swoim nadejściem podniosło wagę tego, co ludzkie, stawiając nie Boga, a człowieka w centrum zainteresowań. ,Jak to sugerował Ernst Cassirer, właśnie w epoce oświecenia we wszystkich dziedzinach kultury zostaje ustanowiony prymat bytu ludzkiego. Do tego stopnia, że Bóg, dotychczas uznawany za

\footnotetext{
26 Tamże, s. 225.

27 Tamże, s. 232
} 
Stwórcę człowieka, zaczyna się jawić jako ludzki wymys ${ }^{228}$. L. Ferry uważa, że ostatnie dwa stulecia to okres ograniczenia dominacji Kościoła i religii, okres laicyzacji. Dziś obserwujemy

z jednej strony [...] odczarowanie świata czy, dokładniej mówiąc, szeroki ruch humanizacji tego co boskie, związany z postępującą od XVIII wieku laicyzacją Europy. Pod hasłem odrzucenia autorytetów i pod sztandarem wolności myślenia, w czasie dwóch ostatnich stuleci dokonuje się bezustanne uczłowieczanie treści zawartych w objawieniu. [...] Z drugiej strony obserwujemy również powolne i nieubłagane uświęcanie tego, co ludzkie [...] to właśnie człowiek jako taki uznawany jest dziś za sacrum $^{29}$.

Procesy te powodują wyparcie sfery transcendencji rozumianej jako zewnętrzna, autorytarna. Stąd tradycyjny charakter pytania o sens życia i jego rozumienia zostaje pozbawiony racji bytu. Sama potrzeba zapytywania jednak pozostaje. Człowiek jako istota duchowa dążenia do prawdy i sensu nie odrzuca, a przenosi w inny obszar. Jest to obszar transcendencji obecnej w immanencji. Prawda i Sens przestają być czymś zewnętrznym, niezależnym od osoby i sytuowanym zawsze ,ponad” i „poza” nią, a przeniesione zostają do jej wnętrza. W ten sposób to, co transcendentne zostało interioryzowane, zachowując tym samym istotne dla człowieka pytania i dążenia. Mamy więc do czynienia z dwoma zjawiskami: ubóstwieniem człowieka i uczłowieczeniem Boga. „Ubóstwieniu człowieka [...] odpowiada pragnienie uczłowieczenia Boga - aby mówił On bardziej do ludzi, był im bliższy - ale także chęć ukształtowania takich stosunków z Bogiem, w których nie byłoby już miejsca na autorytaryzm" 30 .

Bardziej pesymistyczną wizję pytania o sens kreśli V. E. Frankl. Zdaniem tego wyśmienitego austriackiego psychiatry, który starał się mówić o człowieku w perspektywie duchowości, nie można mówić o egzystencji, gdy jednocześnie nie odnosi się jej do tego, co transcendentne. Współczesne nauki zapoznały jednak, twierdzi V. E. Frankl, tę ważną sferę przynależną człowieczeństwu i uczyniły samego człowieka, zamkniętego we własnej immanencji, miarą wszelkich odniesień. Początek owego stanu sięga przewrotu kopernikańskiego, kiedy to percepcja świata w świadomości ludzi uległa odwróceniu o $180^{\circ}$. Z chwila, gdy Ziemia okazała się nie być centrum wszechświata, straciły moc teologiczne opisy rzeczywistości. Antropocentryzm zajął miejsce teocentryzmu. Człowiek postawił siebie na miejscu zdetroni-

\footnotetext{
28 Tamże, s. 43.

29 Tamże, s. 44-45.

30 L. Ferry, Człowiek-Bóg, czyli o sensie życia, Warszawa 1998, s. 48.
} 
zowanego Boga, wyrzekając się tym samym transcendencji w wyjaśnianiu sensu ludzkiego życia ${ }^{31}$.

Według autora Homo patiens jest to równoznaczne z kryzysem nauk traktujących o człowieku, którego przezwyciężenie „uda się, gdy wykażemy transcendentalność bytu ludzkiego"32. Rzecz w tym, pisze dalej V.E. Frankl, „aby wprowadzając transcendencję do nauki o naturze ludzkiej, odtworzyć obraz człowieka, odpowiadający jego istocie, ze znamiennymi cechami jego transcendencji. Prawdziwy obraz człowieka rozrywa bowiem ramy nie tylko tego, co faktyczne, ale i tego, co immanentne" ${ }^{33}$. Osoba ludzka jest odbiciem, obrazem bytu wyższego. Tylko w relacji do sacrum, czyli tego, co transcendentne, człowiek zachowuje faktyczne podobieństwo do pierwotnej pełni istnienia. Odcinając się od tego odniesienia, obraz zostaje zniekształcony. Kondycja ludzi w rzeczywistości XX i XXI wieku jest kondycją krzywych zwierciadeł. Miast oddawać prawdę o człowieku, stają się jedynie obrazami ograniczonymi do immanencji, czyli niepełnymi. Jeżeli transcendencja nie zostanie przywrócona, skazani jesteśmy na poczucie zagubienia czy braku podstawowego wymiaru bycia: jego sensu, co w następstwie rodzi frustrację, smutek i rozpacz. Taka rzeczywistość natomiast nie może zapewnić właściwej podstawy dla prawidłowego wzrostu i rozwoju jednostki ludzkiej. Poczucie bezsensowności własnego istnienia miast budować, co winno być udziałem człowieka, służy destrukcji jego osobowościowych struktur.

W tym miejscu rodzi się wyzwanie, jakie zaistniały stan rzeczy stawia przed edukacja, wyzwanie ponownego wprowadzenia w dyskurs pedagogiczny kwestii prawdy i sensu. Tylko tak można bowiem odpowiedzieć na podstawową i właściwą człowiekowi potrzebę odnoszenia własnej egzystencji do sensu. Dopiero w relacji do tak rozumianej prawdy życia, w relacji do pytania o sens rozwijać się może w pełni istota ludzka. Pedagogika jako nauka zajmująca się człowiekiem i mająca o nim szczególną pieczę, winna wyposażyć się w oręż przeciw niepewności, zwątpieniu, rozpaczy. Winna swe siły skierować na budowanie pozytywnego obrazu świata poprzez uwrażliwianie jednostek na kwestię Prawdy i Sensu, gdyż: „Poszukiwanie prawdy jest walką: bitwą w wojnie przeciwko chaosowi, odwiecznym rytuałem wyrywania rzeczywistości zwątpieniu poprzez nazywanie jej części, zaklęciem, które ma ocalić ją przed pogrążeniem w nicości”34.

Sprawa sensu życia jest sprawą w najwyższym stopniu indywidualna, osobista, prywatną. Nie ma sensu mówić o sensie życia zbiorowości, na

\footnotetext{
${ }^{31}$ V. E. Frankl, Homo, s. 99.

32 Tamże, s. 112.

33 Tamże.

${ }^{34}$ F. Fernández-Armesto, dz. cyt., s. 243.
} 
przykład narodu. Chodzi zawsze o życie jednostki. A tymczasem właśnie najważniejsze sprawy człowieka są czysto prywatne; tak, obok sensu życia, cierpienie, miłość, śmierć i tym podobne. Sensu życia nikt mi nie da. Muszę go znaleźć i zachować sam. Mówimy o sensie i bezsensie przede wszystkim, gdy chodzi o słowa, znaki, mowę. Dane wyrażenie ma sens dla mnie, jeśli ja jego znaczenie rozumiem, a jest bezsensowne, gdy tak nie jest. Życie nie może przecież mieć znaczenia, przynajmniej w tym słowa znaczeniu, w którym wyrażenie je posiada. Ma natomiast, albo przynajmniej może mieć, wartość. Moje życie ma sens, kiedy ja uważam, sądzę, czuję itd., że ono ma wartość dla mnie, czyli prostszymi słowami, kiedy uważam, czuję itd., że warto żyć. To jest, zdaje mi się, jasne. Istnieje jeden wypadek, w którym o sensie życia nie można watpić, a mianowicie wtedy, kiedy istnieje jakiś cel, do którego się dąży, który chciałoby się osiagnąć. Jeśli w danej chwili istnieje cel, do którego dany człowiek dąży, jego życie ma w tej chwili sens. Ale nie zawsze tak jest. Kiedy twój sens życia jest zagrożony, staraj się znaleźć sobie cel, do którego mógłbyś intensywnie dążyć. Jeśli życie danego człowieka ma sens w danej chwili, to on dąży w tej chwili do jakiegoś celu. Istnieją chwile, w których dany człowiek do żadnego celu nie dąży, a w których jego życie ma przecież sens ${ }^{35}$.

Są chwile, w których dążenia nie ma, a sens życia przecież jest. Można więc powiedzieć, że ten sens istnieje w dwóch wypadkach: kiedy człowiek do czegoś dąży i kiedy oddaje się używaniu chwili obecnej. Skoro używanie chwili jest jednym z dwóch sposobów nadania życiu sensu, wolno na marginesie naszego zdania sformułować jeszcze inną regułę moralną: Umiej żyć w chwili obecnej i używać jej! Nie trzeba pogardzać małymi celami i przemijającymi chwilami użycia.

Dążenie do jakiegoś celu nadaje najczęściej ten sens mojemu życiu, muszę, więc dbać, aby mi nie brakło celów. Ale sens znaleźć można nie tylko w dążeniu, bo daje je także, i w wysokiej mierze, używanie chwili. Umieć jej używać, potrafić cieszyć się tym, co mi jest dane teraz, obecnie, jest bardzo wielką rzeczą: wypada mi świadomie się jej uczyć. Życie ludzkie nie jest jednym jedynym szeregiem dążeń, ale składa się na nie cały pęk małych szeregów. Nie trzeba się dać uwieść przez Jedno Jedyne, przez Wielką Sprawę, ale umieć zadowalać się wielością małych i przelotnych zadowoleń. Ta mała filozofia, która jest bodaj mądrością zwykłych ludzi, może dać człowiekowi to trochę szczęścia, jakie jest w ogóle na tym świecie możliwe.

35 J. Michalski, Sens, s. 264-269. 


\section{Creation of Subject Identity in the Context of Sense Category in Pedagogy (Summary)}

Culture provides some philosophical concepts composing fundaments of fair life, suggests solutions to key existential problems, defines social mechanisms for their maintenance. They compose a reference system of social and individual life. The type of social order in which human existence finds its course plays a crucial role in the process of development of own life and identity as it encompasses a framework of context for understanding the world and functioning in it, however always via finding the sense of life. The content of the presentation shall include application of sense category to the pedagogy and an attempt to answer the question: how to liven up the issue of development of sense of life in social life, upbringing, education, pedagogical way of thinking and how to help others to enter the path which would not lead to nothingness but to the plenitude of life and existence.

Keywords: subject identity; existential problems; sense of life; plenitude of life; Frankl.

\section{Konstruowanie tożsamości podmiotowej w kontekście kategorii sensu w pedagogice (Streszczenie)}

Kultura dostarcza pewnych koncepcji filozoficznych stanowiących podbudowę życia godziwego, podsuwa rozwiązania podstawowych problemów egzystencjalnych, ustanawia społeczne mechanizmy ich podtrzymywania. Stanowią one układ odniesienia zarówno dla społecznego, jak i indywidualnego życia. Typ ładu społecznego, w którym przebiega egzystencja człowieka, odgrywa znaczącą rolę w procesie kształtowania przez niego własnego życia i własnej w nim tożsamości, gdyż stanowi ramy zakreślające kontekst rozumienia świata przeżywanego i działania w nim, ale zawsze poprzez odnalezienia sensu życia. Treścią wystąpienia będzie aplikacja kategorii sensu do pedagogiki w jej wymiarze teoretycznym i praktycznym i próba odpowiedzi na pytania: jak zagadnienie kształtowania sensu życia ożywić w życiu społecznym, w wychowaniu, w edukacji, w myśleniu pedagogicznym, jak pomóc ludziom wchodzić na drogę, która nie prowadzi do nicości, lecz ku pełni bytu i życia.

Słowa kluczowe: tożsamość podmiotowa; problemy egzystencjalne; sens życia; pełnia życia; Frankl. 
